\title{
Nursing Motives for Helping Scale (N-MHS): Reliability and Validity
}

\author{
José Luis González Gutiérrez, Cecilia Peñacoba Puente, \\ Ricardo Moreno Rodríguez, Almudena López López, and Lilian Velasco Furlong \\ Universidad Rey Juan Carlos
}

This paper presents the Nursing Motives for Helping Scale (N-MHS), an instrument designed for the evaluation of three of the four motives for helping derived from Batson's helping pathway theory. Dimensionality was analyzed by means of principal component analysis $(n=113)$, followed by confirmatory factor analysis. A 3-factor structure (corresponding to Batson's differentiation among altruistic motivation, reward-seeking motivation, and punishment-avoidance motivation, respectively), with 9 items distributed in three latent variables, revealed an acceptable fit to the data. Alpha values (.60 - .74) showed that internal consistency was acceptable for a newly developed subscale with a small number of items. Convergence validity was evaluated with correlations between N-MHS subscales scores and scores on the Professional Expectations Scale (Garrosa, Moreno-Jiménez, Rodríguez-Carvajal, \& Morante, 2005). The three resulting subscales are a promising instrument for the evaluation of three nursing motives for helping that can contribute to reduce the potential risks and to improve the potential benefits both for the nurse and the patient.

Keywords: motivation to help, nursing, altruism, validity, reliability, questionnaire

En este articulo se presenta la Escala de Motivaciones de Ayuda en Enfermería [The Nursing Motives for Helping Scale (N-MHS)], un instrumento elaborado para evaluar tres de las cuatro motivaciones de ayuda derivadas del modelo de motivación prosocial de Batson. Se analizó la dimensionalidad mediante análisis de componentes principales $(n=113)$, seguido de análisis factorial confirmatorio. La estructura de 3 factores (correspondiendo a la diferenciación de Batson entre las motivaciones altruista, la de búsqueda de recompensa y la de evitación del castigo, respectivamente), con 9 ítems distribuidos en 3 variables latentes, mostró un ajuste aceptable a los datos. Los valores de alfa (.60 - .74) indicaron que la consistencia interna era aceptable para una subescala nueva con un número pequeño de ítems. La validez convergente se evaluó mediante las correlaciones entre las puntuaciones de las subescalas de la N-MHS y las puntuaciones en la Escala de Expectativas Profesionales (Garrosa, Moreno-Jiménez, Rodríguez-Carvajal y Morante, 2005). Las tres subescalas resultantes constituyen un instrumento prometedor para la evaluación de tres motivaciones de ayuda de enfermería que pueden contribuir a reducir los riesgos y a incrementar los beneficios potenciales tanto de los profesionales de enfermería como de los pacientes. Palabras clave: motivación de ayuda, enfermería, altruismo, validez, fiabilidad, cuestionario

Correspondence concerning this article should be addressed to Dr. José Luis González Gutiérrez. Facultad de Ciencias de la Salud, Universidad Rey Juan Carlos, Avda. Atenas s/n, 28922 Alcorcón (Madrid), Spain. Fax: 3491 4888956. E-mail: joseluis.gonzalez@urjc.es Translation: Virginia Navascués Howard 
The concept of "prosocial behavior" consists of a broad variety of actions directed at benefiting others (Batson, 1998), including behaviors such as sharing, cooperating, comforting, and helping, among others. Specifically, this last type of prosocial behavior has been described as a complex behavior, multi-determined by an extensive range of causal factors, moderating circumstances and mediating mechanisms (Dovidio $\&$ Penner, 2004). Among them, both dispositional factors and more strictly situational factors have been identified as relevant elements to explain helping behavior (Bierhoff \& Rohmann, 2004; Eisenberg, 1991; Romer, Gruder, \& Lizzadro, 1986), despite which, empirical efforts have focused primarily on elements of a more contextual nature.

Within this situational framework, Batson and his collaborators (see Batson, 1991) presented the well known empathy-altruism hypothesis that has been the foundation for the development of a voluminous empirical corpus that attempts to demonstrate the existence of true altruism. According to this theory, the presence of another person in a state of need can produce a broad range of emotional experiences in the observer, such as sadness, stress (i.e., worry, displeasure, etc.) or empathic interest (sympathy, compassion, etc.). Thus, whereas sadness or stress can lead to motivations to help of a selfish nature (in which helping behavior is an instrumental means to achieve the final goal of obtaining individual benefits), empathic interest (which corresponds to a specific situational response given by the observer in the presence of another person in a state of need) would generate an altruistic motivation where the final goal of the helping behavior is to benefit others.

Over the past two decades, Batson and colleagues have based their work on the research methods of social psychology (Batson, 1991, 1998) to contrast the above hypothesis. In general, the main axis of these methods is the presence of experimental designs in which the subjects are exposed to a person in a state of need while the helping behavior generated and the emotional response they experience are evaluated. Examining the result of these works, one can observe the presence of a constant: The participants who experience relatively high levels of empathic interest display higher levels of help even when it would be possible to escape from the stressing situation (and so, relieve their own vicariously induced stress), when the decision not to help could easily be justified, when helping apparently does not constitute an instrumental behavior to improve the benefactor's own emotional state, or when situations that generate positive emotions occurred before the opportunity to help arose (Batson, 1991, 1998; Batson \& Oleson, 1991) Batson et al. have thus been able to counter the continuous alternative interpretations about the egoistic nature of the relation between empathic interest and helping behavior (Archer, 1984; Archer, Díaz-Loving, Gollwitzer, Davis, \& Foushee, 1981; Cialdini, Brown, Lewis, Luce, \& Neuberg, 1997; Cialdini et al., 1987; Schaller \& Cialdini, 1988; Smith, Keating, \& Stotland, 1989). However, these same authors recognize the existence of other sources of motivation of an egoistic nature in which helping behavior becomes an instrumental object on the way to the true final goal: obtaining individual benefits. In this case, the primary goals can be diverse: to improve one's own emotional state (shame, remorse, guilt, etc.), eliminate empathic stress, reaffirm a positive selfimage, achieve specific personal goals (for example, a rise in salary), achieve some advantage over the person helped, etc. (Dovidio \& Penner, 2004; Gilbert \& Silvera, 1996). To sum up, such goals have been grouped by Batson as three possible egoistic alternatives in contrast to altruistic motivation: (a) reward-seeking motivation, (b) punishment-avoidance motivation, and (c) motivation based on aversive-arousal reduction (Batson, 1998; Batson \& Coke, 1981).

Along with the analysis of the situational factors, the other important approach to the analysis of the determinants of helping behavior has focused on dispositional factors. This approach is based on evidence about the consistency of prosocial actions over time and across situations (Oliner \& Oliner, 1988; Colby \& Damon, 1992), and advocates the consideration of the interaction between situational and dispositional factors as the main aspect responsible for helping behavior (Carlo, Eisenberg, Troyer, Switxer, \& Speer, 1991; Dovidio \& Penner, 2004), although in this interaction, personal factors play a less substantial role than do situational factors (Oliner \& Oliner, 1988; Piliavin \& Charng, 1990).

Several personality variables have been proposed to be related to prosocial behavior. For example, Staub (1974) developed a prosocial orientation index from the combination of several measures, among which are those related to social responsibility (Berkowitz \& Daniels, 1964; Berkowitz \& Lutterman, 1968; Schwartz, 1968). On the other hand, Rushton (1980, 1981), along with the variables proposed by Staub, indicated the need to consider other factors such as dispositional empathy (including the tendency to assume the other's viewpoint) or self-esteem. This author even dared to refer to the existence of an "altruistic personality," which would integrate the former elements. However, when the true altruistic nature of this personality factor was tested by Batson, Bolen, Cross, and Neuringer-Benefiel (1986), no evidence supporting it was found when the concept of altruism was interpreted by the authors as the search for the welfare of others in the absence of any kind of planned additional personal benefit, including internal rewards (self-administered).

Another development similar to the prosocial orientation index was carried out by Penner, Fritzsche, Craiger, and Freifeld (1995). These authors developed the Prosocial Personality Battery, comprising two factors: other-oriented empathy (the tendency to experience empathy and to feel responsibility and concern for the welfare of others; in other words, prosocial feelings and thoughts) and helpfulness (a self-reported history of involvement in helping activities; in other words, prosocial behavior). This instrument allows the assessment of what they called the "prosocial personality," defined as a continuous tendency to be concerned about others' welfare and rights and to act on that concern to improve the wellbeing of others. 
Lastly, still within the dispositional perspective, an approach of a more functional nature is concerned with the analysis of the goals detected behind helping behavior. This line of research was developed by Omoto, Snyder, Clary and their colleagues (i.e., Clary \& Snyder, 1991; Clary et al., 1998; Omoto \& Snyder, 1990), who distinguished six principal motivations that seem to underlie the involvement and the maintenance of volunteer activities: value-expressive (to express values related to altruistic and humanitarian concern for others), understanding (to acquire new learning, and to be able to practice existing knowledge, skills, and abilities), social (to be with friends and to participate in activities viewed favorably by them), career (to develop activities that may benefit one's professional career directly or indirectly), protective (to protect one's ego from the self's negative aspects and to obtain help to address personal problems), and enhancement (to increase positive feelings towards oneself and to enhance personal growth and development). These six dimensions were the basis of the development of the Volunteer Functions Inventory (Clary et al., 1998). An alternative to this instrument is the Volunteer Motivation Questionnaire (Omoto \& Snyder, 1995), which assesses five motivational dimensions of volunteers, and has been adapted to Spanish by Chacón and his colleagues (Chacón \& Vecina, 1999; Chacón, Vecina, Menard, \& Sanz, 1997).

Again, the functional approach to helping behavior has assumed an interactionist stance, because helping behavior is understood as the result of pairing individuals' motivational characteristics, on the one hand, and the opportunities provided by the environment, on the other (Clary et al., 1998). This approach is necessary if one wishes to advance towards the analysis of helping behaviors that are planned and sustained over time, instead of restricting oneself to the explanation of spontaneous prosocial behavior in specific short-term situations (Clary \& Snyder, 1991). However, the analysis of the motivations underlying planned helping behavior has been basically reduced to the area of volunteerism, and helping professions (i.e., nursing) have received no attention. In contrast, the motivational perspective of helping behavior that has awakened more interest within the area of planned helping activity does not match the perspective developed by Batson and colleagues within the area of situational and spontaneous helping activity (i.e., Batson, 1991, 1998), although, in fact, there is no justification for this. Only Smith, Kleinbeck, Boyle, Kochinda, and Parker (2001) have assumed this perspective, although again in relation to unpaid helping activity. These authors developed a scale that measures three kinds of helping motivation in family caretakers: altruistic motivation, reward-seeking motivation, and punishment-avoidance motivation. However, it is necessary to develop instruments to assess these kinds of motivation in helping professions whose activity is remunerated and non-voluntary, given the recognized risks and potential benefits of each of them, both for the helper and the helped (Batson, 1993; Omoto \& Snyder, 1995; Taylor,
Ford, \& Dunbar, 1995; Toi \& Batson, 1982). We would then be able to count on a useful instrument to analyze in depth some conflictive aspects identified during the study of the working values of these assistantial professionals (probably the topic more closely related to the area of motivation to help within the field of work motivation), as in the work conducted by authors such as Aguilar, García, and Calvo (2004). On the basis of the typology developed by Schwartz (1992, 1994), these authors observed a predominance of individualistic values (looking for particular benefit) over the collectivist ones (whose goal is to help or the welfare of the collective) in a sample of nursing professionals.

In this work, we analyzed the psychometric properties of the Nursing Motives for Helping Scale (N-MHS), made up of three subscales to evaluate altruistic motivation, rewardseeking motivation, and punishment-avoidance motivation within the context of the nursing profession. An additional subscale of motivation based on aversive-arousal reduction was not included because of the potential problems for the factorial discrimination of this dimension (Smith et al., 2001).

\section{Method}

\section{Participants}

The instrument was developed using a sample of 113 nursing professionals who carried out their activity in various attendance centers in two hospitals of the Community of Madrid. Women comprised $90.2 \%$ of the sample and men, the remaining $9.8 \%$. The mean age was 37 years $(S D=$ $8.78)$, with an average of 14 years in the profession $(S D=$ $7.85)$, and of 9.68 years in the same post $(S D=8.78)$. The mean duration of the labor shift was 7.89 hours $(S D=1.70)$, distributed among the morning shift $(42.7 \%)$, the afternoon shift $(28.2 \%)$, the night shift $(10.9 \%)$, and rotating shift (18.2\%).

\section{Instruments}

For the development of the N-MHS, four items were initially created for each dimension, in an attempt to tap the various facets of motivation for helping empirically delimited by Batson (Batson, 1998; Batson \& Coke, 1981) and described by Smith et al. (2001). Due to the known difficulty of developing a subscale to measure motivation based on aversive-arousal reduction (e.g., Smith et al.), 12 items were created that focused on the evaluation of the three remaining dimensions: altruistic motivation, reward-seeking motivation, and punishment-avoidance motivation. The items were a series of statements to which participants rated their degree of agreement on a 5-point Likert-type scale ranging from 1 (totally disagree) to 5 (totally agree). Table 1 shows the three dimensions along with the description of each of the 12 items formulated. 
In order to evaluate the validity of the N-MHS, we administered conjointly the "Escala de Expectativas Profesionales" (EXP, in Spanish the "Professional Expectations Scale"; Garrosa, Moreno-Jiménez, Rodríguez-Carvajal, \& Morante, 2005), which assesses some of the more frequent expectations of work activity (Meier, 1983; Muchinsky, 2000). This scale is made up of 22 items grouped into three subscales to evaluate the three kinds of expectations corresponding to the factors obtained by the authors with exploratory factor analysis: reinforcement expectations, outcome expectations, and efficacy expectations. Each one of the EXP subscales has been negatively associated with related concepts such as, for example, some of the most stressing work factors in nursing, or with the three burnout syndrome dimensions, and positively with the constructs such as work engagement or self-efficacy. The reliability of the subscales, calculated with Cronbach's alpha coefficient in a sample of 473 nursing professionals was satisfactory: .86 (reinforcement expectations), .69 (outcome expectations) and .78 (efficacy expectations).

\section{Statistical Analyses}

Given that the simultaneous presence in any person of different types of motivation to help is perfectly possible
(Batson, Ahmad, Lishner, \& Tsang, 2002), oblimin-rotated principal component analysis was used in order to evaluate the dimensionality underlying the series of the 12 initially proposed items. Four basic criteria were followed to retain and interpret the factors: (a) the magnitude of the change observed in the eigenvalues represented in the scree plot (Cattell, 1966; Nunnally \& Bernstein, 1994), (b) factor loadings equal to or above .40 (Stevens, 1995), and (c) the existence of an underlying theoretical referent for each factor (Zeller \& Carmines, 1980). Subsequently, to contrast empirically the validity of the resulting 3-factor structure, we conducted a series of confirmatory factor analyses on the total sample using structural equation modeling (Crowley \& Xitao, 1997; Mueller, 1996). The covariance matrix was analyzed with maximum likelihood estimation (Hoyle, 1995), using the structural equations program AMOS 5 (Arbuckle, 2003a, 2003b). Thereafter, the internal consistency of the subscales was evaluated with Cronbach's alpha coefficients. In addition, the items of each subscale were analyzed by examining the distribution of the different response options, the inter-item correlations, and the corrected correlations of each item with its corresponding subscale. Finally, to analyze the convergent validity of the instrument, the correlations between the N-MHS subscales and the three EXP subscales were calculated.

Table 1

N-MHS Dimensions, Description of the Type of Associated Motivation, and Summary of the Items initially Formulated for each Category

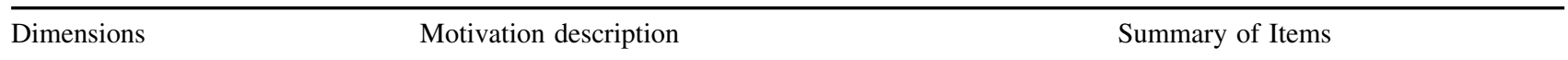

Altruistic motivation

The benefactor tries to identify the receiver's needs and offers the most efficacious kind of help, although this may involve counting on the help of third parties.
1. Obtaining all the necessary attention for the patient.

4. Getting the best for each patient.

7. Analyzing each specific situation to identify the specific attention needs of each patient.

10. Resorting to other colleagues' help to achieve the maximum efficacy when attending the patients.

Reward-seeking The benefactor helps to obtain some kind of motivation reward, although other more qualified people may be present.

Independently of the effectiveness, they will continue helping in order to feel good about themselves.

Punishment-avoidance

The individual helps in order to avoid negative motivation feelings and thoughts (shame, remorse, guilt, etc.) or any other aversive consequence of not helping.
2. Trying to be the main responsible person in the processes of attending patients despite the presence of other more qualified people for certain specific cases.

5. Achieving colleagues' positive perception of one's individual skills in attending the patient.

8. Trying to get ahead of other colleagues so as to be the main responsible person attending the patient.

11. Being the main responsible person attending the patient in order to increase one's own sense of personal efficacy.

3. Attending to avoid other's criticism.

6. Helping at just the right time to avoid the appearance of future remorseful thoughts.

9. Dedicating time to attending the patient to avoid guilty thoughts in the present.

12. Attending the patients while thinking about the guilty thoughts one would have if one did not attend them. 


\section{Results}

The initial principal components analysis yielded a 3factor solution that accounted for $50.8 \%$ of the variance. All the items had loadings over .40. Each one of the three factors extracted corresponded to one of the three pathways of motivation to help proposed: altruistic, reward-seeking, and punishment-avoidance (see Table 2).

Two confirmatory factor analyses were subsequently performed to contrast empirically the validity of the initially proposed 3-factor structure. First, we contrasted a model in which the 12 proposed items were related with just one latent factor. This model, which considers motivation for helping a concept made up of one undifferentiated dimension, showed an inadequate fit to the data, as can be seen in Table 3. Then, the hypothesized model, made up of the 12 observable variables distributed among the three proposed latent factors (in all cases, the loading of the items on the secondary factors was fixed at zero), was tested. The results showed a substantial improvement of this model compared to the former one, although the fit was still unsatisfactory. In this sense, the goodness-of-fit index (GFI) and comparative fit index (CFI) were less than .90, and the root mean square error of approximation (RMSEA) was equal to .08 , which indicated the need to re-specify the model (e.g., Chin, 1998; Hair, Anderson, Tatham, \& Black, 1995; Segars \& Grover, 1993). Consequently, the factor loadings of each manifest variable were analyzed and the model was reformulated, eliminating one variable from each latent factor (items numbers 3,10, and 5), so that the re-specified model was made up of nine variables equally distributed among the three latent factors proposed. Although not entirely satisfactory, the results showed an acceptable fit to the data. The value of $\chi^{2}$, although significant, was near to nonsignificance, $\chi^{2}(24)=$ $40.00, p=.02$, whereas the value of $\chi^{2} / d f$ was below the range of 3:1 (Kline, 1998). Other goodness-of-fit indexes examined fulfilled all the requirements recommended in the literature for each one (GFI and CFI > .90; RMSEA < .08). Only the values of the adjusted goodness-of-fit index (AGFI) and the normed fit index (NFI) were lower than the recommended cutting point (.90). However, some authors suggest a less demanding cutting point (.80) for AGFI and NFI to accept the adequate fit of the model, as both indexes tend to sub-estimate the level of fit when, as in this work, not very large samples are used (Bollen, 1990; Ullman, 2001).

The final solution was therefore made up of nine items, distributed into three latent variables or factors that would correspond to each of the dimensions of motivation to help initially proposed (altruistic, reward-seeking and punishmentavoidance). As can be seen in Figure 1, the correlation between reward-seeking and punishment-avoidance motivations was moderate and significant (.41), whereas the correlations between the altruistic motivation factor and the other two factors were nonsignificant. As shown in Figure 1 , the reliability (internal consistency) of the scale, evaluated by means of Cronbach's alpha coefficient, was also satisfactory, with alpha values ranging from .60 to .74 , fulfilling the criteria usually recommended for new subscales with few items (Zeller \& Carmines, 1980).

Table 2

Principal Components Analysis: Final Factor Solution after Oblimin Rotation

\begin{tabular}{|c|c|c|c|c|}
\hline \multirow[b]{2}{*}{ Item number } & \multicolumn{3}{|c|}{ Factors and factor loadings } & \multirow[b]{2}{*}{$h^{2}$} \\
\hline & $\begin{array}{c}1 \\
\text { Punishment-avoidance } \\
\text { motivation }\end{array}$ & $\begin{array}{c}2 \\
\text { Altruistic } \\
\text { motivation }\end{array}$ & $\begin{array}{c}3 \\
\text { Reward-seeking } \\
\text { motivation }\end{array}$ & \\
\hline 12 & 699 & -.019 & .077 & .650 \\
\hline 9 & 698 & -.002 & .194 & .720 \\
\hline 6 & .664 & -.153 & .205 & .552 \\
\hline 3 & .631 & .086 & -.066 & .418 \\
\hline 4 & -.046 & .843 & .097 & .258 \\
\hline 1 & .176 & .783 & .110 & .652 \\
\hline 7 & -.257 & .690 & .091 & .603 \\
\hline 10 & .008 & .580 & -.270 & .349 \\
\hline 11 & .135 & -.003 & .775 & .427 \\
\hline 8 & .319 & -.063 & .770 & .480 \\
\hline 5 & -.164 & .025 & .544 & .500 \\
\hline 2 & .250 & .224 & .413 & .489 \\
\hline Eigenvalue & 2.385 & 2.216 & 1.497 & \\
\hline Variance explained & $19.87 \%$ & $18.47 \%$ & $12.471 \%$ & \\
\hline
\end{tabular}

Note. Boldface indicates highest factor loadings. 
Table 3

Nursing Motives for Helping Scale (N-MHS). Summary of Results of Confirmatory Factor Analyses

\begin{tabular}{|c|c|c|c|c|c|c|c|c|c|}
\hline Model & $\chi^{2} / d f$ & $p$ & Difference $\chi^{2} / d f$ & $\Delta \chi^{2} / \Delta \mathrm{gl}$ & RMSEA & GFI & AGFI & NFI & CFI \\
\hline 1 factor, 12 variables & $187 / 54$ & .00 & - & - & .15 & .76 & .66 & .35 & .40 \\
\hline 3 factors, 12 variables & $86 / 51$ & .01 & $101 / 3$ & 33,67 & .08 & .89 & .83 & .70 & .84 \\
\hline 3 factors, 9 variables & $40 / 24$ & .02 & $46 / 27$ & 1,70 & .07 & .93 & .86 & .81 & .91 \\
\hline
\end{tabular}

Note: The hypothesized model ( 3 factors and 12 variables) was compared with a one-factor model. In turn, the revised model ( 3 factors and 9 variables) was compared with the hypothesized model.

$\chi^{2} / d f=$ relative chi-square; Difference $\chi^{2} / d f=$ Difference in chi-square; RMSEA = Root mean square error of approximation; GFI = Goodnessof-fit index; AGFI = adjusted goodness-of-fit index; NFI = Bentler-Bonet's normed fit index; CFI = Bentler's comparative fit index.

Except for two cases, the responses to the items were adequately distributed among all the response options. On the other hand, $78 \%$ of the inter-item correlations ranged between the values of .30 and .70 , which indicates content homogeneity but not redundancy (DeVillis, 1991; Nunnally \& Bernstein, 1994). Moreover, the corrected correlation of each item with its corresponding subscale ranged between .34 and .78, and all of them were above the recommended cutting point of .30 (Crocher \& Aligna, 1986; Nunnally \& Bernstein).
According to the result of the confirmatory factor analysis, the three factors obtained were interpreted as subscales and, in order to obtain a simple measure of each subscale, the means of the ratings were calculated for each subject. In Table 4 are displayed the means, standard deviations, and kurtosis of each of the three subscales of the N-MHS obtained with the present sample of professional nurses.

Lastly, we examined the convergent validity of the instrument by calculating Pearson's coefficients between the subscale scores and the scores obtained in the EXP

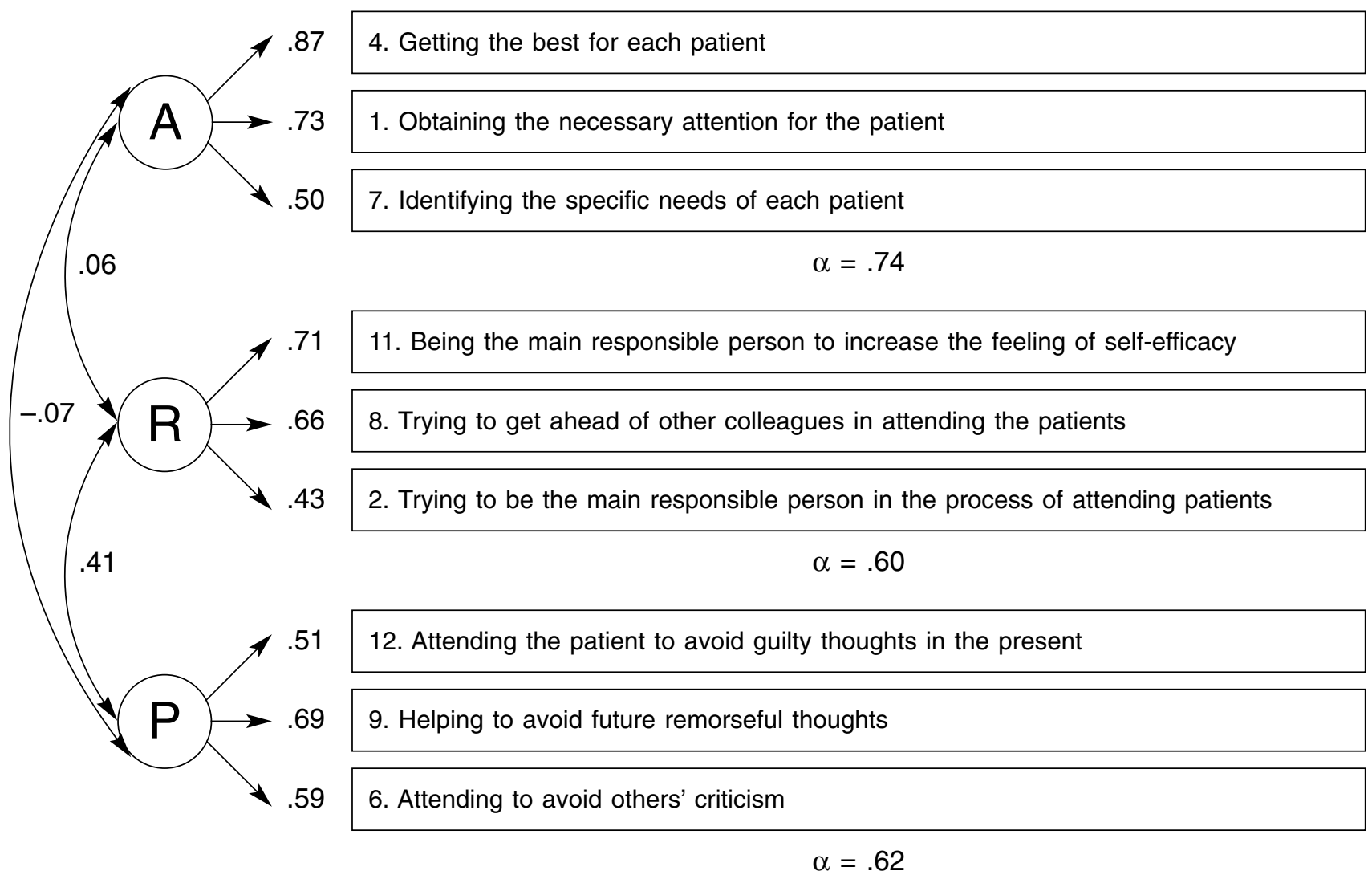

Figure 1. Nursing Motives for Helping Scale (N-MHS). Confirmatory factor analysis with 9 observable variables, showing factor loadings, correlations among factors and internal consistency of each factor (Cronbach's alpha). A = Altruistic motivation; $\mathrm{R}=\mathrm{Reward}$-seeking motivation; $\mathrm{P}=$ punishment-avoidance motivation. 
Table 4

Means, Standard Deviations, and Kurtosis Indexes of the N-MHS Subscales

\begin{tabular}{lcccrr}
\hline & $M$ & $S D$ & Min & Max & Kurtosis \\
\hline Altruistic motivation & 4.31 & 0.53 & 2.00 & 5.00 & 1.82 \\
Reward-seeking motivation & 2.67 & 0.78 & 1.00 & 4.67 & -0.32 \\
Punishment-avoidance motivation & 2.43 & 0.76 & 1.00 & 4.33 & -0.48 \\
\hline
\end{tabular}

Table 5

Pearson's Correlations between the N-MHS Subscales and the EXP Subscales

\begin{tabular}{lccc}
\hline Subscales & Reinforcement expectations & Outcome expectations & Efficacy expectations \\
\hline Altruistic motivation & 0.16 & $0.19^{*}$ & $0.25^{* *}$ \\
Reward-seeking motivation & $0.21^{*}$ & 0.17 & 0.13 \\
Punishment-avoidance motivation & $0.23^{*}$ & 0.07 & 0.00 \\
\hline
\end{tabular}

Note. N-MHS = Nursing Motives for Helping Scale. EXP = Professional Expectations Scale (Garrosa, Moreno-Jiménez, RodríguezCarvajal, \& Morante, 2005).

$* p<.05$. *** $<<.01$.

questionnaire. In Table 5 are presented the correlations between the subscales of both instruments. As can be seen, altruistic motivation had significant correlations with professional outcomes and efficacy expectations, but not with reinforcement expectations. The opposite occurred with reward-seeking and punishment-avoidance motivations, as they correlated with reinforcement expectations, and no significant associations were observed either with outcome expectations or with professional efficacy expectations.

\section{Discussion}

The Nursing Motives for Helping Scale (N-MHS) was created to contribute an assessment tool within an area that is not very developed, such as the study of the motivations underlying planned and remunerated helping behavior within the nursing profession. The results presented herein offer preliminary support to the reliability and validity of the scale, with an acceptable fit to the data of the proposed theoretical model, consisting of three factors: altruistic, reward-seeking, and punishment-avoidance motivation. This fit, although adequate, is not totally satisfactory, given the AGFI and NFI values. Nonetheless, as mentioned above, for some authors, these values would not be at all problematic, taking into account the sample size employed (Bollen, 1990; Ullman, 2001). Along with the global fit of the model, the correlations among the three factors fulfill Batson's theoretical proposals, configuring altruistic motivation independent of the other two factors that represent selfish types of motivation (Batson, 1991, 1998; Batson \& Coke, 1981). In addition, the internal consistency of the resulting subscales, the correlations among the items that make up each subscale, as well as the correlations between each of the items and their corresponding subscales (Crocher \& Aligna, 1986; Nunnally \& Bernstein, 1994) were in all cases satisfactory.

The examination of the convergent validity of the instrument also provided encouraging results. Altruistic motivation is related to outcome expectations (expectations of achieving positive results when attending patients) and efficacy expectations (expectations about performing the work adequately, engagement and involvement, respecting others' rights, and solving work problems adaptively). However, it is not related to reinforcement expectations (expectations of official recognition, of doing things differently, of being able to use one's own judgment, etc.), which, in turn, is related both to reward-seeking and to punishment-avoidance motivations. Moreover, these latter types of motivation (reward-seeking and punishmentavoidance) are not associated with expectations of outcomes or efficacy. These results show that the subscales developed fulfill our expectations, in line with the differentiation established by Batson (Batson, 1998; Batson et al., 2002) between altruistic motivation (where the final goal of helping behavior is to benefit others, so that the expectations will chiefly concern obtaining results and work efficacy) and egoistic motivation (where the final goal is to obtain individual benefits, so that the expectations will be mainly related to obtaining reinforcement).

The above results contribute evidence in favor of the reliability and validity of the Nursing Motives for Helping Scale (N-MHS), an instrument made up of nine items that allows us to evaluate the altruistic orientation of the motivation to help, as well as two of its egoistic alternatives: 
reward-seeking motivation and punishment-avoidance motivation. This scale complements the work initiated by Smith et al., (2001) in the creation of scales to evaluate motivation to help following Batson's taxonomy, but this time, in the sphere of a traditional helping profession. As with any initial presentation of an instrument, this study contributes preliminary data that should be contrasted by means of new works using larger samples of nursing professionals and that allow investigators to continue examining the reliability and validity of the subscales through multiple means related to its convergence, divergence, predictive capacity, etc. Within this context, the analysis of the factor structure of the instrument with larger samples is also desirable. Moreover, the final presence of three items per subscale, although it led to an improvement in the fit of the confirmatory model compared to the alternative of four items per subscale, results in a decrease of the alpha values, and represents some threat to content validity. The analysis of the properties of the instrument in the above-mentioned samples, either starting with the 12 initial items or incorporating new items to the subscales, would be appropriate. Lastly, despite the apparent difficulties involved (Smith et al., 2001), the incorporation of an additional dimension related to the motivation based on aversive-arousal reduction could also enrich the instrument. However, this aspect does not seem easy when considering the multidimensional nature (including the physiological component) of any emotional response (Reeve, 2001). It could be very complicated to discriminate factorially such motivation based on aversive-arousal reduction from other dimensions of motivation to help, where emotions such as guilt or remorse (in which aversive physiological arousal is also characteristic) predominate, especially when the data are collected by self-report measures. In any case, the N-MHS is an especially relevant product, taking into account the scarcity of evaluation instruments in the reference area and given the recognized potential risks and benefits both for the helper and for the help receiver of each of the motivational ways described by Batson (Batson, 1993; Omoto \& Snyder, 1995; Taylor et al., 1995; Toi \& Batson, 1982).

\section{References}

Aguilar, M.C., García, M.A., \& Calvo, A. (2004). Valores hacia el trabajo del personal de enfermería. Un análisis descriptivo. Index de Enfermería, 44-45, 9-13.

Arbuckle, J.L. (2003a). Amos 5.0 [Computer software]. Chicago, IL: SPSS.

Arbuckle, J.L. (2003b). Amos 5.0 update to the Amos user's guide. Chicago, IL: SPSS.

Archer, R.L. (1984). The farmer and the cowman should be friends. An attempt at reconciliation with Batson, Coke and Pych. Journal of Personality and Social Psychology, 46, 709-711.
Archer, R.L., Diaz-Loving, R., Gollwitzer, P.M., Davis, M.H., \& Foushee, H.C. (1981). The role of dispositional empathy and social evaluation in the empathic mediation of helping. Journal of Personality and Social Psychology, 40, 786-796.

Batson, C.D. (1991). The Altruism question: Toward a socialpsychological answer. Hillsdale, NJ: Erlbaum.

Batson, C.D. (1993). A scientific explanation of why we help one another. Lawrence, KS: University Press.

Batson, C.D. (1998). Altruism and prosocial behavior. In D.T. Gilbert, S.T. Fiske, \& G. Lindzey (Eds.), The handbook of social psychology (4 ${ }^{\text {th }}$ Ed., Vol. 2, pp. 282-315). New York: McGraw-Hill.

Batson, C.D., Ahmad, N., Lishner, D.A., \& Tsang, J.A. (2002). Empathy and altruism. In C.R. Snyder \& S.J. Lopez (Eds.), Handbook of positive psychology (pp. 485-498). London: Oxford University Press.

Batson, C.D., Bolen, M.H., Cross, J.A., \& Neuringer-Benefiel, H.E. (1986). Where is the altruism in the altruistic personality? Journal of Personality and Social Psychology, 50, 212-220.

Batson, C.D., \& Coke, J.S. (1981). Empathy: A source of altruistic motivation for helping? In J.P. Rushton, \& R.M. Sorrentino (Eds.), Altruism and helping behavior: Social, personality, and developmental perspectives (pp.167-187). Hillsdale, NJ: Erlbaum.

Batson, C.D., \& Oleson, K.C. (1991). Current status of the empathy-altruism hypothesis. In M.S. Clark (Ed.), Review of personality and social psychology (Vol. 12, pp. 62-85). Newbury Park, CA: Sage.

Berkowitz, L., \& Daniels, L.R. (1964). Affecting the salience of the social responsibility norm. Journal of Abnormal and Social Psychology, 68, 275-281.

Berkowitz, L., \& Lutterman, K.G. (1968). The traditional socially responsible personality. Public Opinion Quarterly, 32, 169185.

Bierhoff, H.W., \& Rohmann, E. (2004). Altruistic personality in the context of the empathy-altruism hypothesis. European Journal of Personality, 18, 351-365.

Bollen, K.A. (1990). Overall fit in covariance structure models: Two types of sample size effects. Psychological Bulletin, 107, 256-259.

Carlo, G., Eisenberg, N., Troyer, D., Switxer, G., \& Speer, A.L. (1991). The altruistic personality: In what contexts is it apparent? Journal of Personality and Social Psychology, 61, 450-458.

Cattell, R.B. (1966). The scree test for the number of factors. Multivariate Behavioral Research, 1, 245 -276.

Chacón, F., \& Vecina, M.L. (1999). Análisis de la fiabilidad de un cuestionario de motivaciones del voluntariado en sida. Psicothema, 11, 211-223.

Chacón, F., Vecina, M.L., Menard, M., \& Sanz, M. (1997). Factores psicosociales que influyen en el voluntariado: Un estudio piloto. Intervención Psicosocial, 17, 105-116.

Chin, W.W. (1998). The partial least squares approach to structural equation modelling. In G.A. Marcoulides (Ed.), Modern 
Methods for Business Research (pp. 295-336). Mahwah, NJ: Erlbaum.

Cialdini, R.B., Brown, S.L., Lewis, B.P., Luce, C., \& Neuberg, S.L. (1997). Reinterpreting the empathy-altruism relationship: When one into one equals oneness. Journal of Personality and Social Psychology, 73, 481-494.

Cialdini, R. B., Schaller, M., Houlihan, D., Arps, K., Fultz, J., \& Beaman, A. (1987). Empathy-based helping: Is it selflessly or selfishly motivated? Journal of Personality and Social Psychology, 52, 749-758.

Clary, E.G., \& Snyder, M. (1991). A functional analysis of altruism and prosocial behavior: The case of volunteerism. In M.S. Clark (Ed.), Prosocial behavior (pp. 119-148). Newbury Park, CA: Sage.

Clary, E.G., Snyder, M., Ridge, R.D., Copeland, J., Stukas, A.A., Haugen, J., \& Miene, P.K. (1998). Understanding and assessing the motivations of volunteers: A functional approach. Journal of Personality and Social Psychology, 74, 1516-1530.

Colby, A., \& Damon W. (1992). Some do care: Contemporary lives of moral commitment. New York: Free Press.

Crocher, L., \& Aligna, J. (1986). Introduction to classical and modern test theory. New York: Harcourt Brace Jovanovich.

Crowley, S., \& Xitao, F. (1997). Structural equation modeling: Basic concepts and applications in personality assessment research. Journal of Personality Assessment, 68, 508-531.

DeVillis, R.F. (1991). Scale development: Theory and applications. Newbury Park, CA: Sage.

Dovidio, J.F., \& Penner, L.A. (2004). Helping and altruism. In M.B. Brewer, \& M. Hewston (Eds.), Emotion and motivation. Perspectives in social psychology (pp. 247-280). Malden, MA: Blackwell.

Eisenberg, N. (1991). Meta-analytic contributions to the literature on prosocial behavior. Personality and Social Psychology Bulletin, 17, 273-282.

Garrosa, E., Moreno-Jiménez, E., Rodríguez-Carvajal, R., \& Morante, M.E. (2005). Variables predictoras del burnout en enfermería: importancia de los procesos emocionales de resistencia. Medicina y Seguridad del Trabajo, 51, 5-13.

Gilbert, D.T., \& Silveira, D.H. (1996). Overhelping. Journal of Personality and Social Psychology, 70, 678-690.

Hair, J.F., Anderson, R.E., Tatham, R.L., \& Black, W.C. (1995). Multivariate data analysis with readings. Englewood Cliffs, NJ: Prentice-Hall.

Hoyle, R.H. (Ed.). (1995). Structural equation modeling: Concepts, issues, and applications. Thousand Oaks, CA: Sage.

Kline, R.B. (1998). Principles and practice of structural equation modeling. New York: Guilford Press.

Meier, S. (1983). Toward a theory of burnout. Human Relations, 36, 899-910.

Muchinsky, P.M. (2000). Psychology applied to work. Belmont, CA: Wadsworth.

Mueller, R.O. (1996). Basic principles of structural equation modeling: An introduction to LISREL and EQS. New York: Springer.
Nunnally, J.C., \& Bernstein, I.H. (1994). Psychometric theory (3 ${ }^{\text {rd }}$ ed.). New York: McGraw-Hill.

Oliner, S., \& Oliner, P. (1988). The altruistic personality: Rescuers of Jews in Nazi Europe. New York: Free Press.

Omoto, A.M., \& Snyder, M. (1990). Basic research in action: Volunteerism and society's response to AIDS. Personality and Social Psychology Bulletin, 16, 152-166.

Omoto, A.M., \& Snyder, M. (1995). Sustained helping without obligation: Motivation, longevity of service, and perceived attitude change among AIDS volunteers. Journal of Personality and Social Psychology, 68, 671-686.

Penner, L.A., Fritzsche, B.A., Craiger, J.P., \& Freifeld, T. (1995). Measuring the prosocial personality. In J.N. Butcher, \& C.D. Spielberger, (Eds.), Advances in personality assessment (Vol. 10). Hillsdale, NJ: Erlbaum.

Piliavin, J.A., \& Charng, H.W. (1990). Altruism: A review of recent theory and research. The Annual Review of Sociology, 16, 2765.

Reeve, J. (2001). Understanding motivation and emotion ( $3^{\text {rd }}$ ed.). New York: Harcourt Brace.

Romer, D., Gruder, C.L., \& Lizzadro, T. (1986). A person-situation approach to altruistic behavior. Journal of Personality and Social Psychology, 51, 1001-1012.

Rushton, J.P. (1980). Altruism, socialization, and society. Englewood Cliffs, NJ: Prentice Hall.

Rushton, J.P. (1981). The altruistic personality. In J.P. Rushton, \& R.M. Sorrentino (Eds.), Altruism and helping behaviour: Social, personality, and developmental perspectives (pp. 251-266). Hillsdale, NJ: Erlbaum.

Schaller, M., \& Cialdini, R.B. (1988). The economics of empathic helping: Support for a mood management motive. Journal of Experimental Social Psychology, 24, 163-181.

Schwartz, S.H. (1968). Words, deeds, and the perception of consequences and responsibility in action situations. Journal of Personality and Social Psychology, 10, 232-242.

Schwartz, S.H. (1992). Universals in the content and structure of values: Theoretical advances and empirical test in 20 countries. In M.P. Zanna (Ed.), Advances in Experimental Social Psychology, (vol. 25, pp. 1-65). London: Academic Press.

Schwartz, S.H. (1994). Are there universal aspects in the structure and contents of human values? Journal of Social Issues, 50, $19-45$.

Segars, A.H., \& Grover, V. (1993). Re-examining perceived ease of use and usefulness: A confirmatory factor analysis. MIS Quarterly, 17, 517-525.

Smith, K.D., Keating, J.P., \& Stotland, E. (1989). Altruism reconsidered: The effect of denying feedback on a victim's status to empathic witnesses. Journal of Personality and Social Psychology, 57, 641-650.

Smith, C.E., Kleinbeck, S.V., Boyle, D., Kochinda, C., \& Parker S. (2001). Family Caregivers' Motives for Helping Scale derived from motivation-to-help theory. Journal of Nursing Measurement, 9, 239-257. 
Staub, E. (1974). Helping a distressed person: Social, personality and stimulus determinants. In L. Berkowitz (Ed.), Advances in experimental social psychology, (Vol. 7, pp. 293-341). New York: Academic Press.

Stevens, J. (1995). Applied multivariate statistics for the social sciences ( $3^{\text {rd }}$ ed.). Hillsdale, NJ: Erlbaum.

Taylor, R., Ford, G., \& Dunbar, M. (1995). The effects of caring on health: A community-based longitudinal study. Social Science and Medicine, 40, 1407-1415.

Toi, M., \& Batson, C.D. (1982). More evidence that empathy is a source of altruistic motivation. Journal of Personality and Social Psychology, 43, 281-292.
Ullman, J.B. (2001). Structural equation modeling. In B.G. Tabachnick, \& L.S. Fidell (Eds.), Using multivariate statistics (4 ${ }^{\text {th }}$ Ed., pp. 653-771). Needham Heights, MA: Allyn \& Bacon.

Zeller, R.A., \& Carmines E.G. (1980). Measurement in the social sciences: The link between theory and data. New York: Cambridge University Press.

Received September 9, 2005 Review received November 21, 2005 Accepted December, 5, 2005 